\title{
PENINGKATAN HASIL BELAJAR MENGGUNAKAN PAKEM DENGAN METODE DISKUSI PADA PEMBELAJARAN FISIKA DASAR POKOK BAHASAN MEKANIKA
}

\author{
Albert Lumbu ${ }^{1}$, Indah Slamet Budiarti ${ }^{2}$ \\ ${ }^{1,2}$ Prodi Pendidikan Fisika Jurusan MIPA FKIP \\ ${ }^{1,2}$ Universitas Cenderawasih
}

\begin{abstract}
ABSTRAK
Penelitian ini dilaksanakan dengan latar belakang hasil belajar mahasiswa semester I angkatan 2013 program studi pendidikan fisika pada pembelajaran fisika dasar pokok bahasan mekanika masih sangat rendah. Hal ini ditunjukkan sekitar 26,09\% mahasiswa yang sudah mencapai nilai ketuntasan, yaitu nilai 60. Penelitian ini bertujuan untuk mengetahui apakah melalui Pembelajaran PAKEM dengan metode diskusi dapat meningkatkan aktivitas mahasiswa dalam pembelajaran serta hasil belajar mahasiswa pada materi mekanika. Penelitian ini merupakan Penelitian Tindakan Kelas yang dilaksanakan pada mahasiswa semester I angkatan 2013 program studi pendidikan fisika dengan jumlah mahasiswa 23 orang. Penelitian dilakukan selama 4 bulan yaitu dari bulan Agustus sampai dengan November 2013. Pengambilan data dalam penelitian ini dilakukan dengan menggunakan teknik observasi dan angket untuk analisis data kualitatif, serta tes penilaian kognitif mahasiswa sebagai analisis data kuantitatif. Hasil penelitian yang diperoleh dari siklus I berdasarkan persentase 47,83\% mahasiswa tuntas belajar, $52,17 \%$ mahasiswa tidak tuntas belajar. Pada siklus II ketuntasan belajar meningkat menjadi $82,61 \%$ mahasiswa tuntas belajar, dan 17,39\% mahasiswa tidak tuntas belajar. Hasil observasi aktivitas mahasiswa pada siklus I diperoleh berdasarkan persentase $31,25 \%$ mahasiswa kategori kurang aktif, 43,18\% mahasiswa kategori cukup aktif, dan 25,57\% mahasiswa kategori aktif. Pada siklus II aktivitas mahasiswa meningkat menjadi 14,21\% mahasiswa kategori kurang aktif, 40,34\% mahasiswa kategori cukup aktif, dan 45,08\% mahasiswa kategori aktif. Hasil penelitian ini menunjukkan melalui Pembelajaran PAKEM dengan metode diskusi terbukti dapat meningkatkan aktivitas mahasiswa dalam pembelajaran dan meningkatkan hasil belajar mahasiswa pada materi mekanika.
\end{abstract}

Kata Kunci : PAKEM, metode diskusi, hasil belajar dan aktivitas mahasiswa

\section{PENDAHULUAN}

Mata kuliah Fisika Dasar merupakan salah satu mata kuliah keahlian dasar yang sangat penting di Program Studi Pendidikan Fisika. Mata kuliah ini diberikan kepada mahasiswa pendidikan fisika pada semester I, mata kuliah ini memberikan dasar terutama untuk kompetensi professional. Kompetensi professional merupakan salah satu dari empat kompetensi yang harus dimiliki oleh guru dan calon guru yaitu meliputi kompetensi paedagogi, kompetensi kepribadian, dan kompetensi sosial.

Bagi seorang guru, mengajar adalah aktivitas utama. Oleh karena itu, ia layak disebut guru, karena ada transfer ilmu kepada siswa. Maka dari itu, sudah menjadi kewajiban guru untuk mempelajari bermacam-macam metode pembelajaran, agar bisa mengajar secara efektif, efisien, dan berkualitas. Pembelajaran menjadi kata kunci dalam meningkatkan kualitas pendidikan.

Pembelajaran yang saat ini dikembangkan dan banyak dikenalkan ke seluruh pelosok tanah air adalah Pembelajaran Aktif, kreatif, Efektif, dan Menyenangkan atau disingkat dengan PAKEM. Disebut demikian, karena pembelajaran ini dirancang agar mengaktifkan dan mengembangkan kreativitas anak, sehingga pembelajaran menjadi aktif, namun tetap menyenangkan.

Materi dan metode adalah dua sisi mata uang yang tidak bisa dipisahkan. 
Materi tanpa metodologi dirasa kurang efektif dan metodologi tanpa materi akan terasa hampa, karena tidak ada yang diolah dan dikembangkan. Dua-duanya penting untuk dipelajari dan dipraktikkan, agar pembelajaran berjalan secara efektif dan berkualitas tinggi.

Metode adalah suatu cara yang dipergunakan untuk mencapai tujuan yang telah ditetapkan. Dalam kegiatan belajar mengajar metode diperlukan oleh guru untuk dipergunakan bervariasi sesuai dengan tujuan yang ingin dicapai setelah pengajaran berakhir. Seorang guru tidak dapat melaksanakan tugasnya bila tidak menggunakan dan menguasai satupun metode mengajar. Diskusi adalah aktivitas dari kelompok siswa berbicara saling bertukar informasi maupun pendapat sebuah topik atau masalah dimana anak ingin mencari jawaban/penyelesaian problem dari segala segi dan kemungkinan yang ada.

Dalam pembelajaran Fisika, tidak hanya sekedar melihat kemudian diingat dan dibayangkan. Agar benar-benar mengerti dan dapat menerapkan ilmu pengetahuan yang diperolehnya, maka mahasiswa harus bekerja untuk memecahkan masalah, menemukan sesuatu bagi dirinya sendiri dan selalu bergulat dengan ide-ide, sehingga konsep-konsep penting tersebut tertanam kuat dalam benak mahasiswa melalui pembelajaran PAKEM dengan metode diskusi.

Penguasaan konsep-konsep fisika terutama pada materi mekanika, mahasiswa semester I angkatan 2013 masih rendah. Hal ini ditunjukkan oleh rendahnya perolehan pretest, yaitu rata-rata 50, sedangkan diharapkan mahasiswa lulus dengan predikat minimal C, yaitu nilai 60 .

\section{METODOLOGI PENELITIAN}

Penelitian ini merupakan Penelitian Tindakan Kelas. Penelitian Tindakan Kelas ini dilakukan untuk mengatasi masalah pembelajaran yang dialami mahasiswa semester I angkatan 2013 program studi pendidikan fisika dalam memahami konsep-konsep mekanika dengan menerapkan pembelajaran PAKEM dengan metode diskusi.

\section{HASIL PENELITIAN DAN PEMBAHASAN \\ Hasil Penelitian Siklus I \\ Berdasarkan hasil observasi} aktivitas mahasiswa diperoleh persentase rata-rata $31,25 \%$ kategori kurang aktif, 43,18\% kategori cukup aktif, dan 25,57\% kategori aktif. Sedangkan hasil penilaian kognitif siswa diperoleh nilai rata-rata siswa pada pra siklus 50,22 meningkat menjadi 55,45 pada siklus I. Berdasarkan hasil penilaian kognitif mahasiswa pada pra siklus terdapat 6 dari 23 mahasiswa $(26,09 \%)$ yang memperoleh nilai $>60$ atau yang telah mengalami ketuntasan belajar. Pada siklus I terdapat 11 dari 23 mahasiswa $(47,83 \%)$ mengalami peningkatan, meskipun belum mencapai ketuntasan belajar klasikal.

\section{Pembahasan Siklus I}

Pada awal pembelajaran dilakukan pretest. Hal ini dilakukan untuk mengetahui sejauh mana kemampuan awal mahasiswa, melalui hasil tes tersebut dosen lebih mudah mengidentifikasi konsep-konsep apa saja yang telah dipunyai oleh mahasiswa. Sebagian besar mahsiswa belum dapat menjawab soal-soal yang diberikan dengan benar. Pada siklus I, pembelajaran dilakukan dengan menerapkan pembelajaran PAKEM dengan metode diskusi. Pada pembelajaran ini, mahasiswa sudah diberikan modul fisika dasar, sehingga mahasiswa bisa mempelajari materi kinematika partikel yang merupakan bagian dari mekanika. Melalui metode diskusi ini, mahasiswa mengerjakan LKS yang sudah disiapkan oleh dosen bersama rekan di dalam kelompoknya. Pada siklus I ini, masih terlihat aktivitas mahasiswa yang rendah, dan hasil belajar kognitif yang belum mencapai ketuntusan. Hal ini disebabkan karena banyak mahasiswa yang belum mengenal baik rekan di dalam kelompoknya, sehingga mahasiswa masih mengerjakan LKS secara individu, belum diskusi di dalam kelompoknya serta banyak mahasiswa yang belum mempelajari modul fisika. Berdasarkan teori belajar yang dikemukakan oleh Jerome Bruner (dalam 
JPFK, Volume 1, Nomor 1, Maret 2015 : 23 - 28

Riyanto, 2007), bahwa belajar penemuan sesuai dengan pencarian pengetahuan secara aktif oleh manuasia, dan dengan sendirinya untuk mencari pemecahan masalah serta pengetahuan yang menyertainya menghasilkan pengetahuan yang benar-benar bermakna. Melalui pembelajaran PAKEM dengan metode diskusi ini mahasiswa melakukan proses mental seperti meramalkan, dan menyimpulkan. Mahasiswa benar-benar terlibat dengan berpikir secara aktif untuk menemukan konsep itu sendiri, mahasiswa akan merasa senang dan bangga, sehingga mahasiswa merasa belajar menjadi lebih bermakna.

Pada akhir pembelajaran diberikan posttest, hasilnya menunjukkan adanya peningkatan dibanding hasil pretest, meskipun masih di bawah batas ketuntasan belajar $(<60 \%)$ dimana dari 23 mahasiswa yang mengikuti pembelajaran, 11 mahasiswa $(47,83 \%)$ tuntas dan 12 siswa $(52,17 \%)$ tidak tuntas. Selama pembelajaran berlangsung satu rekan dosen melakukan observasi terhadap pembelajaran yang dilakukan dosen dan aktivitas mahasiswa selama pembelajaran. Berdasarkan hasil observasi diperoleh persentase rata-rata aktivitas mahasiswa yang kurang aktif $31,25 \%$, cukup aktif 43,18\% dan $25,57 \%$ aktif, tampak bahwa aktivitas mahasiswa kategori kurang aktif masih tinggi sedangkan aktifitas siswa kategori aktif masih rendah, hal ini disebabkan mahasiswa belum seluruhnya terlibat dalam proses pembelajaran, dengan demikian dapat dikatakan aktivitas mahasiswa masih rendah.

Berdasarkan hasil analisis dan refleksi pembelajaran siklus I, diperoleh hal-hal sebagai berikut: Mahasiswa belum mengenal baik rekan di dalam kelompoknya sehingga masih individual, yang mengakibatkan aktifitas mahasiswa masih rendah. Mahasiswa belum mempelajari modul fisika dasar saat pembelajaran berlangsung. Mahasiswa kurang percaya diri dan malu untuk mempresentasikan hasil diskusi kelompoknya sehingga terjadi saling tunjuk.

\section{Hasil Penelitian Siklus II}

Berdasarkan hasil observasi aktifitas siswa diperoleh persentase ratarata $14,21 \%$ kategori kurang aktif, 40,43\% kategori cukup aktif, dan 45,08\% kategori aktif pada siklus II. Sedangkan hasil penilaian kognitif mahasiswa pada tabel 4.4 diperoleh nilai rata-rata mahasiswa pada siklus II meningkat menjadi 67,38\%. Pada siklus II terdapat 19 dari 23 siswa $(82,61 \%)$ mengalami peningkatan dan mencapai ketuntasan belajar baik secara individu maupun klasikal.

\section{Pembahasan siklus II}

Pada siklus II ini, pembelajaran dilakukan pembelajaran PAKEM dengan metode diskusi disertai Handout. Sebelum pembelajaran siklus II dilaksanakan, mahasiswa diberi tugas membuat Handout tentang dinamika partikel Kemudian mahasiswa diminta untuk mengumpulkan tugasnya sehari sebelum pembelajaran siklus II dilaksanakan. Hal ini dilakukan untuk melihat sejauh mana mahasiswa dapat mengerjakan tugasnya dengan baik, membantu dosen dalam mengidentifikasi konsep-konsep apa saja yang telah dimiliki mahasiswa. Berdasarkan tugas yang dikumpulkan sebagian besar mahasiswa sudah membuat Handout dengan benar, meskipun masih ada beberapa mahasiswa yang belum mengumpulkan tugasnya sesuai batas waktu yang diberikan.

Pembelajaran pada siklus II ini pada prinsipnya sama dengan siklus I. Mahasiswa sudah mulai terbiasa dengan pembelajaran yang dilaksanakan, mahasiswa dengan segera memposisikan diri pada kelompoknya masing-masing tanpa kegaduhan.

Setelah dosen melakukan kegiatan awal pembelajaran, masing-masing kelompok diberi LKS dinamika partikel, kemudian mahasiswa diminta mengerjakan LKS dengan diskusi di dalam kelompoknya melalui panduan handout. Kemudian dengan bimbingan dosen, mahasiswa melakukan diskusi, aktivitas mahasiswa tampak cukup aktif, mahasiswa saling membantu dan bekerja sama dalam melakukan kegiatan kelompoknya masing- 
masing. Suasana kelas terkesan ramai dan lebih hidup saat mahasiswa berdiskusi dan membuat kesimpulan. Selanjutnya dosen meminta agar perwakilan tiap kelompok maju ke depan kelas untuk mempresentasikan hasil diskusi kelompoknya dan kelompok mahasiswa yang lain menanggapinya. dosen bersama mahasiswa sepakat menggunakan cara undian agar tidak terjadi saling tunjuk lagi antar mahasiswa seperti pada siklus I. Hal ini cukup berhasil dan mahasiswa bisa menerimanya dengan senang hati. Setelah tiap kelompok selesai mempresentasikan hasil kelompoknya masing-masing, mahasiswa diminta agar mencocokan hasilnya dengan tugas Handout yang dibuat oleh masing-masing mahasiswa. Mahasiswa tampak antusias saling mencocokan dan mengoreksi hasil pekerjaannya.

Berdasarkan komentar mahasiswa dapat disimpulkan bahwa sebagian besar mahasiswa merasa senang dengan pembelajaran yang diterapkan. Melalui Model Pembelajaran PAKEM dengan metode diskusi disertai Handout, dengan bimbingan dosen, mahasiswa lebih mudah memahami konsep-konsep dinamika partikel yang dipelajari berdasarkan penemuannya sendiri.

Selama pembelajaran berlangsung satu orang rekan dosen melakukan observasi terhadap pengelolaan pembelajaran yang dilakukan dosen dan .aktivitas siswa selama pembelajaran. Dari hasil observasi aktivitas mahasiswa pada tabel 4.3 terlihat adanya peningkatan persentase aktivitas mahasiswa dalam kategori aktif. Sedangkan terjadi penurunan persentase aktivitas mahasiswa dalam kategori kurang aktif. Untuk kategori kurang aktif $14,21 \%$, cukup aktif $40,34 \%$, dan aktif 45,08\%. Hal ini menunjukan mahasiswa sudah mulai terbiasa dan merasa senang terhadap pembelajaran yang dilaksanakan. Berdasarkan hasil yang diperoleh dapat disimpulkan bahwa pembelajaran PAKEM dengan metode diskusi dapat meningkatkan aktivitas mahasiswa dalam pembelajaran.
Pada akhir proses pembelajaran dilakukan posttest, dimana butir soal test lebih dikembangkan yang dijadikan alat ukur. Ternyata dari hasil posttest siklus II, umumnya mahasiswa sudah dapat menjawab soal yang diberikan dengan benar. Hal ini menunjukan umumnya mahasiswa sudah memahami materi mekanika. Penilaian kognitif mahsiswa siklus II pada tabel .4 diperoleh nilai ratarata mahasiswa sebesar 67,38. Hal ini menunjukan adanya peningkatan dibandingkan siklus I, yakni terdapat 19 dari 23 siswa $(82,61 \%)$ yang memperoleh nilai $>60$ atau yang telah mengalami ketuntasan belajar, baik secara individu maupun klasikal. Dari hasil analisis dan refleksi hasil pembelajaran siklus II dapat disimpulkan bahwa penerapan pembelajaran PAKEM dengan metode diskusi disertai Handout pada materi mekanika dapat meningkatkan aktivitas mahasiswa pada proses pembelajaran yang berdampak pula pada meningkatnya penguasaan konsep mahasiswa. Standar Ketuntasan Belajar Minimum telah tercapai $(>60 \%)$, sehingga siklus tidak dilanjutkan lagi.

Setelah pembelajaran siklus I dan siklus II, dilakukan pengisian angket respons mahasiswa untuk melihat sejauh mana pendapat mahasiswa terhadap ketertarikan dan perasaan senang, kemudahan memahami materi/isi pelajaran, suasana belajar dan cara guru mengajar serta pendekatan pembelajaran yang digunakan. Berdasarkan jawaban mahasiswa pada angket respons diperoleh persentase rata-rata sekitar $78 \%$ mahasiswa menjawab "Ya" sedangkan 22\% siswa yang menjawab "Tidak". Hal ini menunjukkan bahwa respon mahasiswa terhadap pembelajaran yang dilaksanakan sangat baik. Mahasiswa merasa lebih senang belajar melalui pembelajaran PAKEM dengan metode diskusi yang disertai dengan handout, karena mahasiswa merasa pembelajaran yang dilakukan lebih bermakna dibandingkan belajar dengan metode ceramah, dimana mahasiswa terlibat aktif dalam diskusi serta mempelajari konsep yang akan diajarkan 
JPFK, Volume 1, Nomor 1, Maret 2015 : 23 - 28

dengan membuat handout. Mahasiswa mengatakan belajar melalui pembelajaran PAKEM dengan metode diskusi, mahasiswa aktif berpikir dan beraktivitas, sehingga konsentrasi dan semangat belajar mahasiswa dapat dipertahankan hingga pembelajaran berakhir.

Berdasarkan hasil observasi pembelajaran melalui pembelajaran PAKEM dengan metode diskusi disertai handout telah mengalami perubahan hasil. Berdasarkan persentase rata-rata aktivitas mahasiswa menunjukkan bahwa penerapan pembelajaran PAKEM yang dikembangkan dapat meningkatkan aktivitas mahasiswa.

Berdasarkan hasil penelitian ini bahwa dengan menerapkan pembelajaran PAKEM dengan metode diskusi disertai handout dapat meningkatkan hasil belajar mahasiswa pada materi mekanika serta dapat pula meningkatkan aktivitas mahasiswa dalam pembelajaran. Hasil penelitian ini didukung oleh teori-teori belajar dari Bruner dan Ausubel, serta penelitian yang telah dilakukan oleh Aldi Madrista, bahwa dengan penerapan metode diskusi dapat meningkatkan penguasaan konsep IPS. Penelitian ini juga sejalan dengan penelitian yang telah dilakukan oleh Herry Hidayat, bahwa penerapan pembelajaran PAKEM dapat meningkatkan pemahaman konsep biologi.

Berdasarkan hasil kedua penelitian yang telah dilakukan memiliki persamaan pada tindakan yang dilaksanakan/diberikan yaitu menggunakan pembelajaran PAKEM dan metode diskusi, tetapi penelitian ini mengkombinasikan antara pembelajran PAKEM dengan metode diskusi yang disertai handout. Pada penelitian ini menekankan pada aktivitas belajar dan hasil belajar mahasiswa, sedangkan penelitian yang telah dilakukan sebelumnya (relevan) hanya menekankan pada hasil belajar siswa.

Berdasarkan kajian teori-teori belajar dan hasil penelitian sebelumnya yang telah mendukung penelitian ini menunjukan bahwa dengan menerapkan pembelajaran PAKEM dengan metode diskusi dapat meningkatkan aktivitas belajar dan hasil belajar mahasiswa pada pokok bahasan mekanika.

\section{PENUTUP}

Kesimpulan

Berdasarkan hasil dan pembahasan melalui pembelajaran PAKEM dengan menggunakan metode diskusi dan Handout , penulis mengambil kesimpulan sebagai berikut :

Melalui pembelajaran PAKEM dengan menggunakan metode diskusi disertai Handout pada pokok bahasan mekanika dapat meningkatkan aktivitas mahasiswa dalam pembelajaran, dengan hasil pada siklus I diperoleh persentase rata-rata $35,91 \%$ kategori kurang aktif, $40,00 \%$ kategori cukup aktif, 24,09\% kategori aktif. Sedangkan pada siklus II diperoleh persentase rata-rata 11,36 kategori kurang aktif, 40,91\% kategori cukup aktif, dan 47,36\% kategori aktif.

Melalui pembelajaran PAKEM dengan menggunakan metode diskusi disertai Handout pada pokok bahasan mekanika dapat meningkatkan aktivitas mahasiswa dalam pembelajaran, dengan hasil siklus I ketuntasan sebesar 47,83\% dan nilai kognitif rata-rata 55,45 ternyata dapat meningkat pada siklus II dengan ketuntasan mencapai $82,61 \%$ dan nilai kognitif rata-rata 67,38

\section{Saran}

Berdasarkan kesimpulan di atas, maka saran yang dapat disampaikan penulis adalah sebagai berikut:

Pembelajaran PAKEM dengan metode diskusi disertai Handout, agar pelaksanaan pembelajaran berjalan dengan efektif dan menyenangkan, maka dosen hendaknya memperhatikan dan merancang pembelajaran dengan lebih baik.

Pada awal pembelajaran setiap pokok bahasan, sebaiknya mahasiswa dibiasakan membuat handout agar mahasiswa memiliki pengetahuan awal dan kesiapan mahasiswa dalam proses pembelajaran.

Untuk penelitian lebih lanjut, pembelajaran PAKEM dengan metode 
JPFK, Volume 1, Nomor 1, Maret 2015 : 23 - 28

diskusi disertai handout diuji cobakan pada pokok bahasan yang lain.

\section{DAFTAR PUSTAKA}

Depdiknas.2005. Penelitian Tindakan Kelas (Pelatihan Terintegrasi) Depdiknas Direktorat Jenderal Pendidikan Dasar dan Menengah, Direktorat Jenderal Pendidikan Lanjutan Pertama.

Erwin Sucipto dkk. 1996. Mekanika dan Termodinamika, Diktat Fisika Dasar I, Jurusan Fisika ITB : Bandung

Jamal Ma'mur Asmani. 2011. 7 Tips Aplikasi PAKEM. Diva Press : Jakarta

Kunandar. 2008. Langkah Mudah Penelitian Tindakan Kelas Sebagai Pengembangan Profesi Guru. Jakarta: PT Raja Grafindo Persada.

R. Resnick dan D. Halliday. 1994. Fisika (terjemahan P.Silaban dan E.Sucipto) Jakarta : Erlangga.

Rochiati Wiriaatmadja. 2009. Metode Penelitian Tindakan Kelas. Bandung : Remaja Rosdakarya

Sutrisno. 1986. Seri Fisika Dasar Mekanika, Penerbit ITB : Bandung

http://aldimadrista. Blogspot....(diakses tanggal 2 Desember 2013)

http://www.google.com....(diakses tanggal 2 Desember 2013) 